\title{
Building policy capacity within contextual and political boundaries: an analysis of policies in fiscal and social areas in Brazil (1988/2016)
}

Maria Rita Loureiro ${ }^{1}$

Fernanda Lima-Silva ${ }^{1}$

Adriana Aranha ${ }^{1}$

Felipe Calabrez ${ }^{1}$

${ }^{1}$ Fundação Getúlio Vargas - Escola de Administração de Empresas de São Paulo - SP, Brasil

The current debate on state capacity, despite practical relevance for policy-making and analytical advances in the last decades, is still permeated by several theoretical and methodological problems. Considering that a revised concept of policy capacity has analytical utility, this work has contributed to the literature in three interrelated ways. First of all, we work on the concept of state capacity, highlighting its specificities in regard to the generic notion of power. Secondly, this article shows the relevance of bringing contextual and political elements into the debate of capacity. Thirdly, it helps to establish clearer boundaries on this notion, marking its differences to concepts such as resources and results. Empirically, it analyzes policy capacity developments in areas that have expressed priorities in the governmental agenda in former Brazilian presidencies. In the government of Fernando Henrique Cardoso, the focus is on the fiscal function of the state as a guarantor of credibility for investors, having as a case study the National Treasury Secretariat (STN), within the Ministry of Finance. In Lula's and Dilma's terms, the attention is the social area: the National Secretariat of Citizenship Income, within the Ministry of Social Development, and the National Secretariat of Housing, within the Ministry of Cities, both created at the beginning of the government Lula.

Keywords: state capacity, policy capacity, political priorities 


\section{Construindo capacidade de produção de políticas públicas diante de limites contextuais e políticos: análise de políticas nas áreas fiscal e social no Brasil $(1988 / 2016)$}

O debate contemporâneo sobre capacidade estatal, apesar da relevância prática para policymaking e dos avanços analíticos das últimas décadas, ainda é permeado por diversos problemas teóricos e metodológicos. Levando em conta que um conceito revisado de capacidade de produção de políticas públicas (policy capacity) tem utilidade analítica, este trabalho contribuiu para a literatura de três maneiras inter-relacionadas. Em primeiro lugar, trabalhamos com o conceito de capacidade estatal, destacando suas especificidades em relação à noção genérica de poder. Em segundo lugar, o artigo mostrou a relevância de trazer elementos contextuais e políticos para o debate sobre capacidade. Em terceiro lugar, ajudou a estabelecer limites mais claros entre essa noção e alguns de seus correlatos, como recursos e resultados. Empiricamente, o trabalho analisou o desenvolvimento da capacidade de produção de políticas públicas em áreas que expressaram prioridades na agenda de governos brasileiros recentes. No Governo de Fernando Henrique Cardoso, o foco esteve na função fiscal do Estado como garantidor de credibilidade para os investidores, tendo como estudo de caso a Secretaria do Tesouro Nacional (STN), dentro do Ministério da Fazenda. Nos mandatos de Lula e Dilma, o centro das atenções foi a área social: a Secretaria Nacional de Renda da Cidadania, dentro do Ministério do Desenvolvimento Social, e a Secretaria Nacional de Habitação, dentro do Ministério das Cidades, ambas criadas no início do Governo Lula.

Palavras-chave: capacidade estatal, capacidade de produção de políticas, prioridades políticas

\section{Creación de capacidad para producción de políticas públicas dentro de límites contextuales y políticos: un análisis de políticas en las áreas fiscal y social en Brasil $(\mathbf{1 9 8 8} / \mathbf{2 0 1 6})$}

El debate actual sobre la capacidad estatal, a pesar de la relevancia práctica para la formulación de políticas y de los avances analíticos en las últimas décadas, aún está permeado por varios problemas teóricos y metodológicos. Teniendo en cuenta que un concepto revisado de capacidad para producción de políticas públicas (policy capacity) tiene utilidad analítica, este trabajo ha contribuido a la literatura de tres formas interrelacionadas. En primer lugar, trabajamos en el concepto de capacidad estatal, destacando sus especificidades con respecto a la noción genérica de poder. En segundo lugar, el artículo mostró la relevancia de incorporar elementos contextuales y políticos al debate de la capacidad. En tercer lugar, ayudó a establecer límites más claros entre esta noción y algunos de sus correlatos, como los recursos y los resultados. Empíricamente, el trabajo analizó el desarrollo de la capacidad para producción de políticas públicas en áreas que expresan prioridades en la agenda gubernamental en las recientes presidencias brasileñas. En el gobierno de Fernando Henrique Cardoso, la atención se centró en la función fiscal del estado como garante de credibilidad para los inversores, teniendo como caso de estudio la Secretaría del Tesoro Nacional (STN), dentro del Ministerio de Finanzas. En los gobiernos de Lula y Dilma, el centro de atención fue el área social: la Secretaría Nacional de Ingresos de Ciudadanía, dentro del Ministerio de Desarrollo Social, y la Secretaría Nacional de Vivienda, dentro del Ministerio de Ciudades, ambos creados en el inicio del gobierno Lula.

Palabras claves: capacidad estatal, capacidad de producción de políticas, prioridades políticas 


\section{Introduction}

Pioneer research on state capacity emerged in the mid-twentieth century, anchored in reflections on the increasing complexity and expansion of governmental functions in the economic area with Keynesian policies, and in the social area, with the expansion and consolidation of the Welfare State. In the 1980s, this debate was taken up by historical institutionalists in the United States who analyzed the role of the state in economic development in late industrialized countries in Asia and Latin America (SIKKINK, 1991; EVANS, 1995, 2004) and in social revolutions (SKOCPOL, 1979).

Emphasizing the state as an analytical object, the debate in political theory - once centered on societal processes, seen as determinants of governmental decisions, such as class struggle, competition and conflict between interest groups - moved to state institutions and actors, and their power and actions. Consequently, not only has a broad literature on public policy emerged, but also one on state capacity to formulate and implement policies.

Later, debate on state capacity reemerged in an economic and ideological context different from that of its origin. Relating to the fiscal crisis of the State that affected particularly indebted countries in Latin America and Asia throughout the 1980s and 1990 s, and to the second generation of neoliberal reform proposals, focused not on the dismantling of the State but on the improvement of governmental action, the concept of state capacity started to be discussed by approaches to good practices, such as transparency and efficiency (SCHNEIDER \& DONER, 2000). In Brazil, this debate has also been reintroduced in the last decade with the reinsertion of developmentalism in the public agenda during the governments of Lula and Dilma (GOMIDE \& PIRES, 2014). In this new context, capacity is no longer about the autonomy of state, but about the ability to implement public policies and to dialogue with external stakeholders.

In this article, we do not intend to review the debate on state capacity, which has already been done by several authors who point out current challenges and analytical problems in this literature. Such problems refer to the absence of a theoretically elaborated definition of the concept of state capacity, with the term being often used as a mere expression of common sense and in a polysemic way. Inconsistencies also involve tautological reasoning, ambiguity in causal relationships between variables, and resulting problems of operationalization and measurement. With a research agenda more linked to 
policymakers, the discussion lacks further theoretical grounding and generates empirical analyzes in which the variables that are often used to define capacity - institutions, bureaucracy, infrastructure - are often the same as those used to determine the results of capacity (GOMIDE et al., 2018; SAGUIN et al., 2018; Gomide et al., 2017; LINDVALL \& TeOrell 2016; Wu et al., 2015; Cingolani, 2013; EnriqueZ \& Centeno, 2012; HANSON \& SigMAN, 2011; \& KOCHER, 2010). In spite of these problems, we understand that the concept, besides its practical importance for policymakers, being related to economic development and lasting social change, has analytical utility.

Taking into account the idea of state capacity as a form of power (LINDVALL \& TEORELL, 2016), we adopt an understanding that any analysis of state capacity, particularly in democratic societies, cannot be separated from broader considerations on the context in which public policies are inserted, including the political and ideological priorities of those in power positions in governments. Differently from the notion of power, frequently used in generic terms, this concept of state capacity is relevant because it allows a more accurate understanding of the process by which political actors who, having drafted a government project, are able to garner support and counteract potential vetoes, while at the same time, to use the administrative apparatus of the state to execute that project. In other words, this concept unravels the concrete functioning of the state in action, with its technical and specialized officials, financial and information resources to carry out the governmental projects. The concept of state capacity could even be thought of as the fulfillment of the "prince's virtue", who is able to circumvent the "contingencies of fortune".

As the literature has already pointed out (LindVALL \& TEORELL, 2016; Cingolani, 2013), it is necessary not to confuse the concept of state capacity with the achievement of goals or results, which may also be affected by contingencies external to governmental action. It is also relevant to be cautious and not to misunderstand this concept with the mere existence of indicators of stock of resources (specialized staff, structured careers, volume of financial resources, etc.). These indicators express a necessary but not sufficient condition for the apprehension of state capacity. If they already exist, they must be activated by political decisions.

The diagnosis of state capacity, therefore, is an inference based on an analysis in which the actions of political actors (elected officials and bureaucrats) are oriented to the implementation of priority projects and, for this, they create or activate stocks of 
resources. It is never enough to reinforce that the results obtained on a policy implementation can be partly determined by state capacity, which is produced by the deliberate and "virtuous" action of the rulers, and partly by external contingencies.

In addition, it is important to clarify that the concept of state capacity refers to the generic ability of state officials to make and execute a decision. Considering that it is made up of several dimensions, such as coercive, fiscal, administrative, legal, etc. (CINGOlani, 2013), the literature has recently started to use the concept of policy capacity, understood as a set of analytical, operational and political resources and competences necessary for developing specific policy functions, being applied in different levels - individual, organizational and systemic (WU et al., 2015).

In the present work we aim to bring political and ideological governmental orientations and historical-conjunctural context as relevant variables into the debate of policy capacity. Based on Lindvall and Teorell (2016), we consider that the creation or activation of resources (human, financial and informational) are crucial expressions of policy capacity. We also argue that the mobilization of these resources derives from the dispute between political groups that compete for power and influence. We assume that this revised concept is useful to understand how the correlation of political forces at a given historical-conjunctural moment is expressed in the state apparatus mobilized to implement policies. This dimension is still rarely approached in the literature.

State institutions can express capacity already in place, but they can also reflect and condense the political forces in dispute. Thus, changes in power and in contexts can contribute to increase or decrease the resources available to a given area of policy (and programs under its responsibility), creating non-existent areas or eliminating others that already exist. The figure below presents our analytical model. 


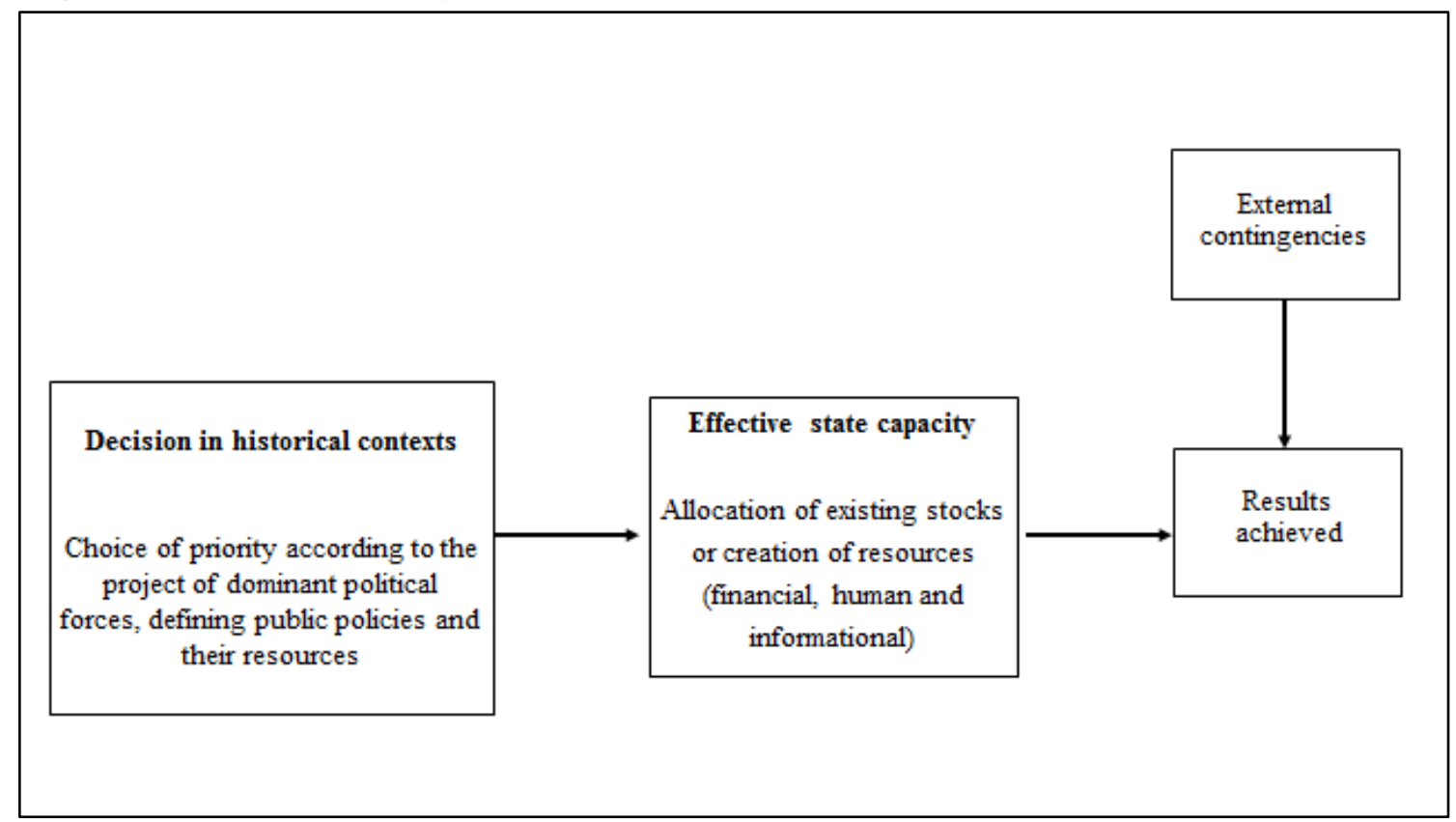

Source: Elaborated by authors.

Through this analytical lens, we examine the capacity-building process of some policies in the fiscal and social areas in the Brazilian State. Our argument is that the mobilization of resources, which conforms effective state capacity in different policy areas, is affected by the political-ideological orientations of governments. Therefore, the research question is: how have different political-ideological orientations of the government influenced the allocation of resources to generate the necessary policy capacity at a given historical context?

The text is composed of the following parts: firstly, methodological considerations are approached and then the political and economic conjunctures and orientations of the analyzed governments. Thereafter, policy capacity building in each of the selected state agencies is analyzed separately. Final considerations are also presented.

\section{Methodological considerations}

This work uses the research method of the case study, which is considered the most appropriate in providing answers to 'How?" and 'Why?' questions and to explaining contemporary events over which the researcher has little control (ROWLEY, 2002; YIN, 1994). In more specific terms, it develops a multiple-case study, aiming to understand and compare different cases in a historical perspective. This research strategy was chosen 
because it allows the detailed and contextualized understanding of the mechanisms that explain the phenomenon of interest, contributing to theory development and improvements in conceptualization (MAHONEY, 2005). That said, its results cannot be generalized without careful considerations regarding historical contexts.

In the present study, we take policy capacity developments in social and fiscal areas as our case studies. The selection of cases in the fiscal area for Cardoso's government and in the social area for Lula and Dilma's governments was based on comprehensive literature pointing to them as priorities in the agenda of these governments (AlÉm \& Giambiagi, 2000; RAMOS, 2001; Oliveira \& Turolla, 2003; LOUREIRO et al., 2011; BICHIR, 2016; SOARES et al., 2010; SOARES \& SÁTIRO, 2009; KLINTOWITZ, 2015; LIMA-SILVA \& LOUREIRO, 2018). It is worth to pinpoint that (i) the selected case studies represent extreme examples, receiving a visible priority status in the presidential agenda, while many other policies were subject to varying levels of governmental effort and commitment, (ii) and that these priority areas don't necessarily refer to the totality of the policy arena, but to sections of the broad areas.

The period analyzed in the Brazilian federal governments goes from the 1990's to mid-2010's. Firstly, we investigate Fernando Henrique Cardoso's (hereinafter FHC) government, from the Brazilian Social Democracy Party - PSDB (1995 - 2002), that, in a context of monetary instability, prioritized inflation and public debt control, austerity policies and other fiscal measures in order to guarantee credibility for investors (ALÉM \& Giambiagi, 2000; RAMOS, 2001; OliveIRA \& TUROLla, 2003; LOUREIRO et al., 2011). The case study focuses in the National Treasury Secretariat (STN), an agency of the Ministry of Finance. For comparison, two agencies of social areas are taken as case studies in the government of Lula (2003-2010) and Rousseff (2011-2016), both from the Workers' Party - PT. Anchored on a pro-poor agenda and in a context of economic stability, these governments, in general, prioritized policies that dealt with poverty reduction (SOARES et al., 2010) and social housing (KLINTOWITZ, 2015; LIMA-Silva \& LOUREIRO, 2018). These two areas were so relevant in the governmental agenda that new Ministries were created to manage them on the first year of Lula's mandate: the Ministry of Social Development (hereinafter MDS) and the Ministry of Cities (hereinafter MCIDADES). In the first we analyze the National Secretary of Citizenship Income (SENARC), and in the second, its National Secretariat of Housing (SNH). 
Considering that qualitative research, when compared to quantitative studies, is subject to a higher degree of subjectivity in their procedures, selection, and management and analysis of their data, it requires as much clarity and transparency as possible when reporting the procedures adopted by researchers (BELTRÃO \& NOGUEIRA, 2011). The table below presents an overview of the data collected and analyzed, the indicators used to evaluate the allocation of resources, which were selected based on the literature on state capacity, specifically the definition of informational, human and financial resources proposed by Lindvall and Teorell (2016), and the indicators of results ${ }^{1}$.

\footnotetext{
${ }^{1}$ Although the analytical framework of these authors does not incorporate institutional aspects, it is worth mentioning that the development of the analyzed policies required building institutional resources, such as the creation of government agencies and legal rules that have guaranteed some continuity, even when these policies ceased to be priorities. Some examples are, in the social area, Law no. 10,386/2004, which created the Bolsa Família Program and the Basic Citizenship Income Law, no. 10,835 / 2004. In the housing sector, relevant rules for building institutional capacity were Law 11.124 / 2005, which established the National Social Interest Housing System (SNHIS) and Law 11.977 / 2009, which created PMCMV, as well as the varied and detailed laws and degrees issued to regulate others aspects of this policy, explored by LimaSilva and Loureiro (2018). In the fiscal area, Decree $\mathrm{N}^{\circ}$. 94.443/1987, that transferred the public debt management from the Central Bank (BACEN) to the STN and Decree $\mathrm{n}^{\circ} 4.643 / 2003$, which defines STN as the area of the Ministry of Finance responsible for "managing the domestic and external public and contractual debts, internal and external, of direct and indirect responsibility of the National Treasury".
} 
Table 1 - Overview of the indicators and data used in the research

\begin{tabular}{|c|c|c|c|c|}
\hline & $\begin{array}{l}\text { Sources and types of } \\
\text { data }\end{array}$ & Resources mobilized/ activated & $\begin{array}{l}\text { Indicators - } \\
\text { Resources }\end{array}$ & $\begin{array}{l}\text { Results of policy } \\
\text { capacity }\end{array}$ \\
\hline $\begin{array}{l}\text { Ministry of } \\
\text { Finance/ National } \\
\text { Treasury } \\
\text { Secretariat }\end{array}$ & $\begin{array}{l}\text { - Literature review } \\
\text { - Other sources: official } \\
\text { statistics }\end{array}$ & $\begin{array}{l}\text { - Human: expansion of staff through public examination; } \\
\text { specialization, training and financial valorization of workers, } \\
\text { including Bonus for Performance and Productivity (GDP) } \\
\text {-Informational: creation of Integrated System of Financial } \\
\text { Administration of the Federal Government - SIAFI } \\
\text { - Financial: increase of financial resources }\end{array}$ & $\begin{array}{l}\text {-Candidate-Vacancy } \\
\text { Relationship } \\
\text { - Improvement of } \\
\text { educational } \\
\text { background of staff } \\
\text { (only masters or } \\
\text { PhD) }\end{array}$ & $\begin{array}{l}\text { - Centralized } \\
\text { management of public } \\
\text { debt } \\
\text { - Increase in the } \\
\text { importance of } \\
\text { government bounds for } \\
\text { macroeconomic policies } \\
\text { and state financing }\end{array}$ \\
\hline $\begin{array}{l}\text { MDS / National } \\
\text { Secretary of } \\
\text { Citizenship } \\
\text { Income }\end{array}$ & $\begin{array}{l}\text { - Literature review } \\
\text { - Documents from } \\
\text { MDS } \\
\text { - National Budgetary } \\
\text { Law } \\
\text { - Data obtained with } \\
\text { the Ministry of } \\
\text { Planning through an } \\
\text { official request of } \\
\text { Access to information } \\
\text { Law }\end{array}$ & $\begin{array}{l}\text { - Informational: creation of the Single Registry (Cadastro } \\
\text { Único) and of an evaluation and information management } \\
\text { structure (Secretariat for Evaluation and Information } \\
\text { Management-SAGI) } \\
\text { - Human: creation and expansion of a specialized staff through } \\
\text { public examinations; increase of professionals in the } \\
\text { decentralized network through management incentives } \\
\text { (creation of the Decentralized Management Index); training } \\
\text { courses for the entire network (CapacitaSUAS) } \\
\text { - Financial: significant increase in investment }\end{array}$ & $\begin{array}{l}\text { - Annual evolution of } \\
\text { budgetary resources } \\
\text {-Annual quantity of } \\
\text { public servants. } \\
\text { - Number of } \\
\text { Registered Families } \\
\text { in CadÚnico }\end{array}$ & $\begin{array}{l}-3.4 \text { million people } \\
\text { stopped living in extreme } \\
\text { poverty for and } 3.2 \\
\text { million left the poverty } \\
\text { line (2017) } \\
-13 \text { million and } 800 \\
\text { thousand families served. }\end{array}$ \\
\hline $\begin{array}{l}\text { MCIDADES } \\
\text { National } \\
\text { Secretariat } \\
\text { Housing }\end{array}$ & $\begin{array}{l}\text { - Literature review } \\
\text { - Data obtained with } \\
\text { the Ministry of } \\
\text { Planning through an } \\
\text { official request of } \\
\text { access to information. }\end{array}$ & $\begin{array}{l}\text { - Human: creation and expansion of a specialized staff through } \\
\text { public examinations (MCIDADES and Caixa) } \\
\text { - Financial: significant increase in investment } \\
\text {-Informational: development of diagnosis, studies and } \\
\text { projections to plan housing policies and subsidy decision- } \\
\text { making }\end{array}$ & $\begin{array}{l}\text {-Annual quantity of } \\
\text { public servants } \\
\text {-Annual evolution of } \\
\text { budgetary resources }\end{array}$ & $\begin{array}{l}\text { Development of the } \\
\text { largest federal programs } \\
\text { on slum upgrading and } \\
\text { social housing (more } \\
\text { than } 4 \text { million new } \\
\text { housing units) }\end{array}$ \\
\hline
\end{tabular}

Source: Elaborated by authors.

REVISTA DO SERVIÇO PÚBLICO | Brasília 71 (special) 7 - 37 Oct. 2020 


\section{The External context and the main governmental orientations in the fiscal and social areas}

Considering that state capacity to elaborate and implement public policies is not a fixed feature, but contingent on the correlation of political forces in certain historical contexts (SKOCPOL, 1985) $)^{2}$, it is necessary to keep in mind that both the context and the political-ideological orientation of government influence the mobilization of resources for policy capacity. In other words, the historical context provides the boundaries for public action, but policymakers still have some choices among these limits, which are influenced by the political and ideological orientations of their political affiliations.

If in the context of globalized economy, the control of public accounts and debt became structural, turning into a permanent priority function of all governments, in other public policies, in particular the social ones, these processes can be met with more or less intensity in function of the dynamics of the economic cycles and each government's orientation. Thus, we briefly analyze how the requirements for inserting Brazil in the globalized economy, from the 1990s onwards, have generated needs related to the restructuring of the national state apparatus. Lula's government, for example, was able to initiate a process of building institutional capacity for the social area, without changing policy capacity previously installed in the fiscal area.

\section{II.1 FHC's government (1995-2002): fiscal area reinforced and fragmented social policies}

Controlling inflation and achieving monetary stabilization were key issues of FHC's presidency (CARDoso, 1994; ABRUCIO \& LOUREIRO, 2004; BELluZzO \& ALMEIDA, 2002). Concomitantly, this government was oriented by neoliberal policies and by the premise to leverage the country's insertion in the global economy. Therefore, it

\footnotetext{
2 As this author has mentioned, state autonomy can come and go as bureaucratic organizations are transformed both internally and in their relationship with social groups and other parts of government. Accordingly, to other authors, state capacity should not be analyzed detached from the political and institutional context in which it is inserted, depending also on a project - goals that were legitimized through election of certain political groups - and political support for such actions (GOMIDE et al, 2017).
} 
prioritized controlling public debt to guarantee investors' credibility, which implied in strengthening and consolidating governmental apparatus in charge of these tasks.

Despite the centrality that FHC's government attributed to the control of expenditures, public debt increased substantially during his two terms. This is justified by the strategies for maintaining stability, which were based on high interest rates and overtaxed the public debt (BELluzzo \& AlMEIDA, 2002; MiRANDA, 1997). In this regard, it can be said that the public debt absorbed the costs of the monetary stability strategy, greatly increasing the amount of government bonds offered to the market for the purposes of fiscal and monetary policy, which probably would not have been possible without an agency endowed with great operational capacity.

FHC was able to set up an institutional engineering that seemed appropriate to modify the macroeconomic scenario, including the concentration of monetary authority in the Central Bank and the great power granted to the Ministry of Finance. Over his two terms, this agency played an important role in driving the increase in tax revenues and the growth of the tax burden in the country (ABRUCIO \& LOUREIRO, 2004). In addition, during the 1999 economic crisis, already in his second mandate, the need for adjustments intensified, requiring a surplus generation policy, used as a guarantee of solvency for the market, which resulted in more stringent expenditure and public indebtedness control initiatives, for example, with the enactment of the Fiscal Responsibility Law (LOUREIRO et al., 2011).

The outcome of this policy guided by fiscal bias and the guarantee of monetary stability compromised the development of social policies. Looking at income transfer and social housing policies in FHC's government, the social areas analyzed here, they were marked by institutional advances and fragmented programs. Pioneer national income transfer programs were launched by several ministries in a focused manner, with different access doors and information systems and benefits, in a scenario of difficult interinstitutional coordination.

On their turn, federal housing policies were marked by reduced investments, institutional fragmentation and a series of small reforms associated with private market regulation and reduction of risks that contributed to unlocking housing production, allowing a small increase after 1996, and grounding the housing construction boom in the next government (MARQUES, 2017, p. 9). 


\section{II.2 Lula and Dilma's Governments (2003 - 2016): maintenance of fiscal management and prioritization of social areas}

Differently from Cardoso's government, in which resources for social areas did not increase significantly and policies were implemented in a fragmented way, Lula's government can be characterized by a double agenda (SINGER, 2012). It simultaneously maintained the fiscal policy built by the former president and promoted progress in the social areas. In the area related to fighting poverty, the institutionalization process started in 2003 with the creation of the Extraordinary Ministry of Food Security and Fight against Hunger and the Ministry of Social Assistance, as well as with the launch of the Zero Hunger Program. The different conditional income transfer initiatives inherited from the previous government were unified, originating the Bolsa Família Program (PBF), at the end of 2003. The consolidation of this process occurred in 2004. Previously fragmented initiatives - the areas of social assistance, food security and conditional income transfer were gathered into a single institution with the creation of MDS. The National Secretary of Citizenship Income (SENARC) manages PBF, which has become one of the main social programs of the country.

As regards to housing policy, Ministry of Cities, a long-standing demand from social movements that supported the new government, was established on the first day of Lula's administration. After 2007, this Ministry acquired relevance in governmental agenda, in particular the National Secretariat of Housing (SNH), which was in charge of an important part of the works of the Program of Growth Acceleration. From 2008 onwards, as an answer to the international economic crisis, Federal government triggered countercyclical policies and launched Brazilian largest housing program: Program My House My Life (PMCMV), which aimed to build 1 million housing units for different income brackets, through the joint action of the three levels of government and the private sector (LOUREIRO et al., 2013). In sum, Lula and Dilma's governments were able to prioritize social policies and mobilize resources for their implementation, while also privileging the fiscal policy, which, on its turn, was central to Cardoso's government. Next, the case studies that make up this research will be analyzed. 


\section{The Progressive construction of capacity in the fiscal area}

From the late 1970s onwards, the transformation of international capitalism, which led to the deregulation and liberalization of finances and changes in economic paradigms, were accompanied by transformation in the administrative structures of the National States. Included in this process, although marked by several peculiarities, the Brazilian State began to reveal a series of dysfunctionalities between the administrative structure responsible for its budget, and the exhaustion of the former development model that, from that moment on, started to impose a series of adjustments. Pressure from international organizations made it imperative to centralize the state's revenue and expenditure structure and increase governmental control capacity over the budget.

International pressures and administrative challenges caused by by government accounting and financial disorganization, which encompassed a fragmented and decentralized public budget and lack of reliable information, were elements that, in 1986, led to the creation of the STN, a body allocated within the Ministry of Finance and responsible for the unified control of the budget and public debt management. Two interconnected processes explain the creation of STN: i) Need for centralized control over the federal budget, including the prerogatives of releasing and contingent resources; ii) Increased importance of public debt, both as a form of state financing and its interdependence with macroeconomic variables; in the new context of globalized capitalism, public debt became an indicator of fundamental importance for the maintenance of macroeconomic stability and market confidence ${ }^{3}$.

In sum, the increased importance of public debt in the context of the country's integration in the globalized economy has raised and maintained STN's relevance within the institutional structure of the Brazilian State. This process was accompanied by functional specialization of STN's internal bodies, increasing the complexity of its activities and even greater appreciation of its professional staff, contributing to the increase in analytical and operational capacity at the individual and organizational levels (WU et al., 2015). This was done through: i) creation of sub-secretariats, subdivided into general coordinators responsible for increasingly complex and specialized tasks; and ii)

\footnotetext{
3 "The fiscal anchor has gained the status of factor that reduces the country-risk and the contagion effect of international crises, standing as the centerpiece in efforts to gain investors' confidence" (HELLER, 1997 apud LOPREATO, 2006, p. 7).
} 
recognition of its technical staff, with programs to expand careers and salaries and attract skilled labor, with a high technical level.

Initially, it is important to highlight that public debt management, completely concentrated on STN, involves complex administrative tasks that include studies on government bounds composition, financing strategies and risk management. As a result, the accumulation and complexity of functions was accompanied by an increase in its organizational structure and the qualification of staff with the appropriate type of expertise to carry out these functions. This process of functional specialization and technical training was marked by important stages of institutional improvement, among which the creation of the General Coordination of Public Debt Administration (CODIP), responsible for the administration of internal debt, and the establishment of the General Coordination of External Affairs (COREX), which was then focused on the external debt accounting record, both dating from 1988. In the 2000s, in the midst of an intense process of international diffusion of ideas and practices aimed at improving public debt management, the debt coordination areas underwent an institutional restructuring, CODIP and COREX were reorganized into three new areas, all under the coordination of the Deputy Secretary of Public Debt.

Regarding STN's civil servants, they are reasonably insulated from other Federal Executive institutions and, above all, from the political-partisan system. In fact, it is a selective insulation process (Silva, 2015), in which the impermeability of the Treasury in relation to the political system occurs along a close interaction between STN and the financial market. In addition, reflecting STN's increasing importance, there was a notable and gradual effort of professional qualification of its civil servants, mainly characterized by the diffusion of international knowledge on public debt management practices (RochA, 2009) as well as salary increases. Therefore, in 1994, during the Real Plan, measures were taken to recover career wages and attract professionals with higher qualifications. This same year, STN would develop a variable remuneration system called Performance and Productivity Bonus (GDP), which would be paid according to the institutional and individual evaluation of each public servant. It is interesting to note that after 1995 no more civil service examinations were carried out for high-school level, only for higher education. Salary recovery and the prestige increase can also be noticed by the proportion growth of the applicants/ candidates per place observed in the last civil service examinations for STN: according to official data by IPEA related to civil service 
examinations at STN, launched in 2009, while in 2002 there were 37 applicants per place, this number rose to 107 in 2008.

With regard to informational resources, in order to carry out its functions, STN implemented a system of budget financial execution, which, less than a year later, gave rise to the Integrated System of Financial Administration of the Federal Government $(\mathrm{SIAFI})^{4}$. Creation of this system was successful and today all the financial inflows and outflows pass through STN'S unified budget and computerized system. One obvious consequence of this reorganization process of the state structure is the increase in the Finance Ministry's capacity to control public finances. Informal systems on public debt management strategy and risk management have also been constantly developed.

In short, STN's capacity building trajectory was in fact a continuous process of accumulation of resources (particularly human and informational) to enhance policy capacity in this area ${ }^{5}$. The strengthening of capacity for fiscal policy was, therefore, in line with certain priorities that are historically situated, strongly emerging on the government of FHC and remaining active on the governments of Lula and Dilma. After all, the institutional development of STN goes hand in hand with the increase in importance of the federal debt (system of government bounds operated by the STN) in macroeconomic policies and the financing of the Brazilian State. In other words, the creation of state capacity in this area seems to be essential to making this model of State financing viable.

\section{The intermittent process of building capacity in social housing policies}

In the early 1980s, the National Housing Bank (BNH), the first large-scale housing initiative in Brazil, began to show signs of exhaustion and financial difficulties. This bank was extinguished in 1986, and its functions were assigned to Caixa Econômica Federal (hereinafter CAIXA). Since then, a process of institutional instability and fragmentation

\footnotetext{
${ }^{4}$ According to STN, the functions of SIAFI are "integrate budgeting, financial execution and accounting systems; use more advanced technology, including online transaction processing; centralize and standardize procedures related to budget execution; be mandatory for direct administration, and allow the implantation of a single Treasury account" (STN, 2006, p. 96).

${ }^{5}$ Even though it was not possible to access disaggregated data on STN's budget, it is reasonable to suppose that the increase on the human and informational resources was anchored on the elevation of its financial resources.
} 
of federal housing policies began, given the lack of resources and the reduced priority in the presidential agenda. ${ }^{6}$

Between 1986 and 2002, subnational governments assumed a leading role in the development of housing policies (CARDOSO \& RIBEIRO, 2002). During the two terms of FHC's government (1995-2002), with the prioritization of inflation control and the stabilization of the economy, housing policy was merely viewed as a financial and market matter and it only received normative advances from federal government (KLINTOWITZ, 2015, p. 119). Against this backdrop, the decentralization of urban policies was accompanied by a lack of federative coordination and by heterogeneous municipal capacity for implementing housing policies (ABRUCIO, 2005).

Lula's election represented a change in the correlation of forces between political actors, impacting on the emergence of urban policy as an important element in the developmental project of the government. An evidence of this is the creation, on Lula's first day of government, of the MCIDADES, a Ministry entirely dedicated to urban issue, gathering into a single institution the different sectoral areas that compose the urban policy, including our case study, the National Housing Secretariat (SNH).

In the context of budgetary and financial constraints of Lula's first mandate and the need to qualify knowledge on the urban issue and policy alternatives, MCIDADES initially focused on its institutional structuring. In terms of human resources, this meant the creation of a specialized staff, composed by experienced public officers that had already worked with urban policy in subnational governments and a rare combination of "union activists, professionals and academics with previous participation in public administration experiences and very prestigious in the technical and academic environment, in addition to strong insertion in urban social movements" (MARICATO, 2012, p. 26) ${ }^{7}$. SNH also worked to improving its organizational-political skills, which was carried out through the establishment of the Cities Council and the National System of Social Interest Housing (SNHIS) and its informational resources, particularly through the formulation of studies and diagnoses on the housing sector, as well as demand

\footnotetext{
${ }^{6}$ From 1986 to 2003, housing issues within federal government were subordinated to seven different ministries or administrative structures (KLINTOWITZ, 2015).

${ }^{7}$ This excerpt, as well as other in the article, were translated by the authors from Portuguese into English.
} 
projections for social interest housing ${ }^{8}$, that were used to support planning processes, such as the National Housing Plan.

In reaction to the international crisis of 2008 and based on the informational and human resources accumulated in MCIDADES, urban and housing issues obtained, in the second term of Lula government, a priority status with the Growth Acceleration Program and My House My Life Program (PMCMV), as can be seen in the excerpt below:

\begin{abstract}
When PAC was set up, with Minister Dilma and Miriam Belchior at SAM (Coordination and Monitoring Subsection), there we have effectively become a government priority. Housing and policy programs became part of the first echelon of government (LIMA-SILVA \& LOUREIRO, 2018, p. 545-546)
\end{abstract}

This brought significant political consequences: on the one hand, receiving the PAC stamp meant the inclusion in a centralized decision-making and intensive monitoring process, and, on the other hand, a remarkable increase in financial resources and exemption from any budgetary constraints (LOUREIRO et al., 2013). These new programs changed the scenario: they became the most important housing policy implemented in the country (CARDOSO et al., 2011; ROLNIK et al., 2014) and constituted a new moment in the history of social housing and slum upgrading interventions, due to the unprecedented and much higher amount of investment in these areas of public policy (DiAs, 2012; KLINTOWITZ, 2015; CARDOSO \& DENALDI, 2018). Rousseff's administration maintained these housing programs, although PAC-UAP, due to implementation difficulties, was reduced and PMCMV was relaunched and expanded.

The emergence of these priority programs, in particular, PMCMV, had double meaning. On the one hand, it delegated to the MCIDADES a more normative role, particularly the standardization of the program norms, while the construction enterprises assumed a central role in the elaboration and execution of the social housing projects (DIAS, 2012). The Presidency and CAIXA assumed responsibilities for, respectively, the centralized decision-making process and the operationalization of the housing and social policies (KLINTOWITZ, 2015). On the other hand, the decision to use housing policy as a strategy to leverage economic growth after the 2008 global financial crisis raised this policy's political-systemic capacity, increasing its legitimacy vis-à-vis other federal policies and even other urban policies. In other words, MCIDADES loses agenda power

\footnotetext{
${ }^{8}$ Among these studies are the research on housing deficit, carried out by the João Pinheiro Foundation in 2005, on precarious settlements, from Ministério das Cidades/CEM (Marques, 2007), and on estimates of future demand for new housing, prepared by Cedeplar/UFMG in 2007.
} 
in the urban area, but the legitimacy of its programs and the mobilization of its human and financial resources increases.

During Lula's second term and Dilma's governments, in spite of critics and implementation problems found in PAC-UAP (CARDOSO \& DENALDI, 2018) and in PMCMV (KLINTOWITZ, 2015; CARDOSO et al., 2011), the programs, particularly the latter, were able to achieve the expected results and to deliver more than 4 million new social housing units. An analysis of these programs' implementation makes evident the process of creation and activation of resources for their development. Besides the improvement in informational resources, mentioned previously, this can be noticed in $\mathrm{SNH}$ and in other institutions involved in the execution of these programs, such as CAIXA. A clear indicator of this process is the increase in the volume of financial resources invested in housing programs between 2006 and 2014: federal government invested $\mathrm{R} \$ 2.52$ billion reais $^{9}$ in housing policies in 2006 and $\mathrm{R} \$ 19.55$ billion in $2014^{10}$ (KLINTOWITZ, 2015, p. 239).

The analysis of budget allocation among MCIDADES's Secretariats makes it clear the prominent role played by $\mathrm{SNH}$, as shown in Chart 1. In a low-budget entanglement that includes almost all departments of this Ministry, SNH distinguishes itself from the others by incredibly higher levels of allocated resources.

\footnotetext{
$91 \mathrm{U} \$=\mathrm{R} \$ 3.79$ (July 29 $9^{\text {th }} 2019$ ).

${ }^{10}$ The evolution of budget resources analyzed here include the following programs: PAC-UAP, PMCMV and FNHIS (National Fund for Social Interest Housing, which is associated with SNHIS).
} 


\section{Chart 1 - Budget allocation in MCIDADES' secretariats (2008-09/2017) (in Reais)}

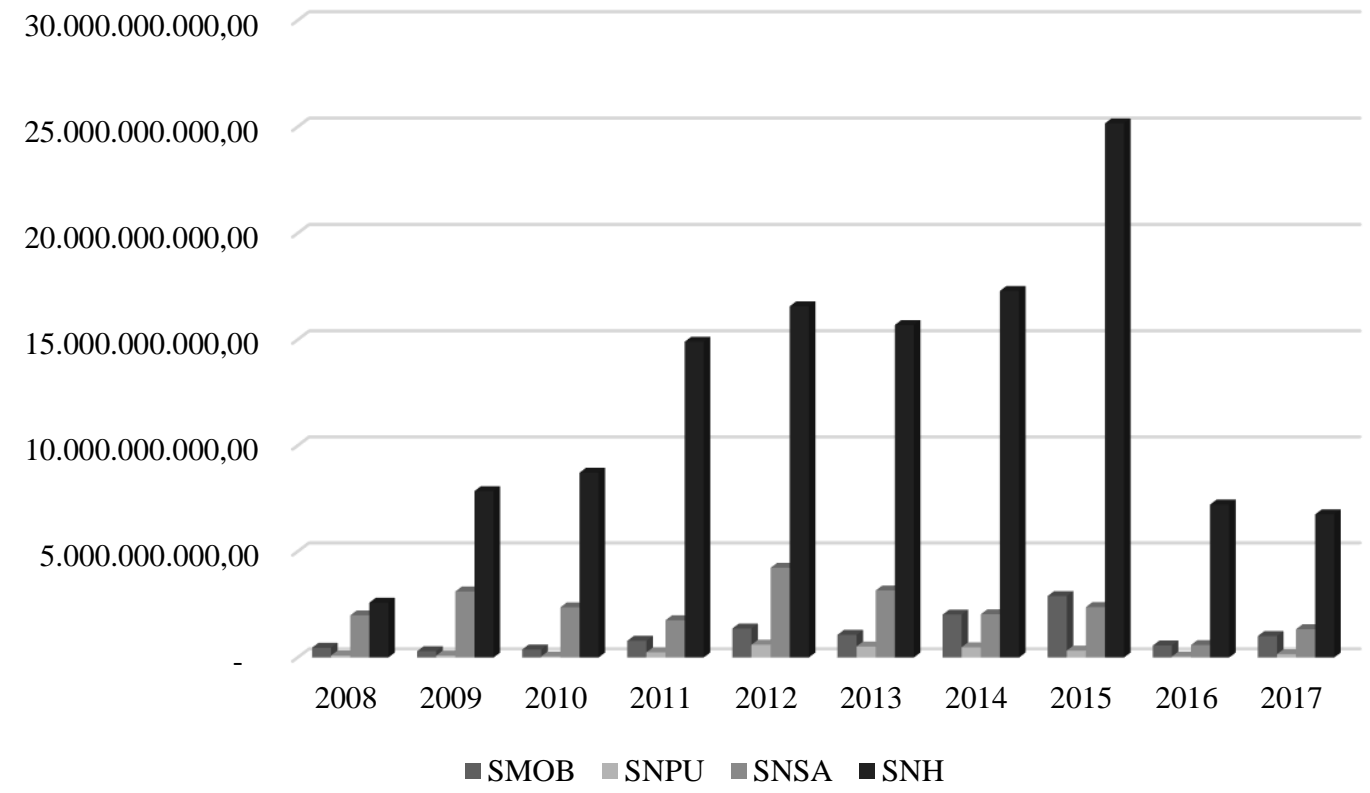

Source: Elaborated by the authors with data obtained with the Ministry of Planning through an official request of access to information. Data range from 2008 to October 2017.

In addition, MCIDADES capacity can be analyzed by looking at its human resources. From 2003 onwards, the Ministry has significantly expanded its staff, encompassing engineers, architects, social workers, and environmental specialists. It almost tripled its number of employees, as it can be seen in Chart 2. An important step was taken with civil service examinations related to the careers of Social Policy Technical Analyst and Infrastructure Analyst, which were held in 2012/2013. Likewise, CAIXA expanded its scope of engineers to monitor the execution of the works (BRASIL, 2010a, p. 27). 


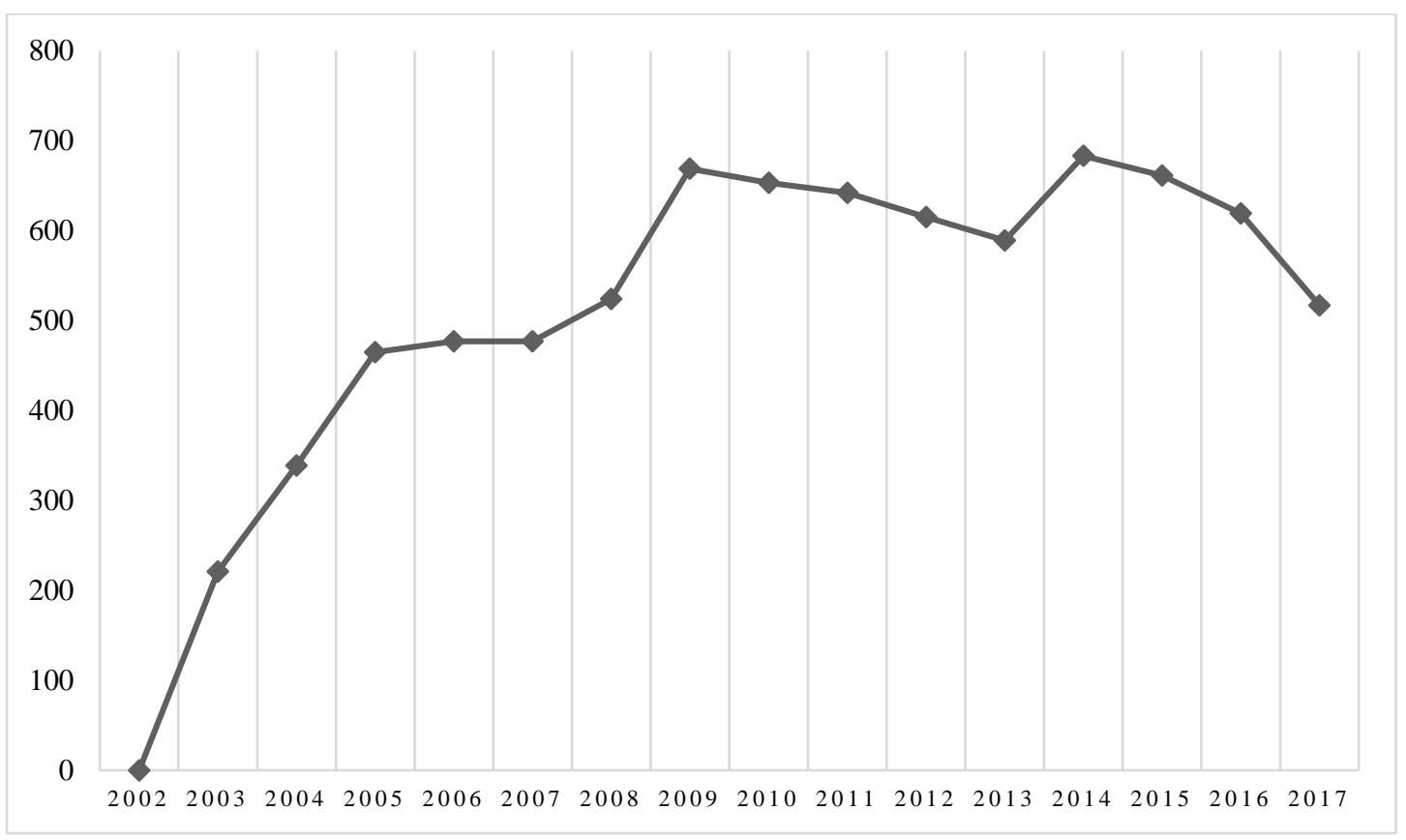

Source: Elaborated by the authors with data obtained with the Ministry of Planning through an official request of access to information. Data range from 2003 to October 2017.

This gradual process of capacity building for housing policies, which included increases in financial, informational and human resources, was supported by PT's prioritization of this issue and by the availability of fiscal resources for public investments, particularly from Lula's second mandate on. However, this process was halted from 2015 onwards. Shortly after Dilma Rousseff's re-election, the political and economic crisis intensified and the balance of power between political actors began to change. With the impeachment and the new government of Michel Temer, in 2016, there is a transformation in the correlation of political forces and in the ideological orientations of the ruler. Based on an economic contingency agenda, the new government has reduced the legitimacy of the ongoing social housing programs and the resources available to MCIDADES. Charts 1 and 2 reflect the changing political and economic context and its impact on the resources: financial investment increased almost steadily until 2015, with a sharp drop in 2016/2017; human resources increased progressively until 2009, when it began to have an intermittent trajectory, and a constant decrease from 2014 onward.

In short, the analysis of this case anchors the claim that the development of capacity for housing policies resulted from the prioritization of housing issues in the developmental agenda of Presidents Lula and Rousseff, generating a gradual process of accumulation of resources (financial, human and informational) to elaborate and 
implement this policy. In alignment with our argument, this process was significantly influenced by changes in the economic context and in the political-ideological orientation of new governments.

\section{Building capacity in social assistance policies}

The trajectory of the social assistance area in Brazil has also been marked by institutional and programmatic intermittency. The 1988 Constitution established, for the first time, the responsibility of the State to ensure social protection to the entire population, defining social assistance as a non-contributory public policy.

This policy includes the implementation of programs and projects that fight poverty, as determined in the Organic Law of Social Assistance - LOAS (Law 8742/93). According to Cardoso Júnior and Jaccoud (2005), FHC's government launched new initiatives to reduce poverty, such as programs for eradication of child labor, to protect elder and disabled groups, with monetary benefits and some conditional income transfer programs. Notwithstanding, these programs were characterized by institutional, programmatic and informational fragmentation and by operational challenges, in a scenario of difficult inter-institutional coordination. This scenario changed with the launching of MDS in 2004, deriving from the integration of three areas with themes that were highly esteemed by the president and his political party and that were previously carried out by different programs and institutions: Food and Nutrition Security, Social Assistance and Income Transfer. With varied trajectories, these three social areas had already assumed leading roles in the presidential agenda since 2003, when Lula took office.

Indeed, MDS's creation was a turning point regarding institutional strengthening for planning and implementing large-scale social policies. This Ministry became responsible for managing Programa Bolsa Família (PBF), which aggregated the previous conditional income transfer initiatives and became the country's largest and most wellknown social policy. Furthermore, PBF contributed to heating up the consumption economy among the low-income population and to reduce social inequality in the country. SENARC, the department responsible for PBF's operationalization, receives special focus within our MDS analysis. 
MDS's launching and gradual consolidation helped to enhance the politicalsystemic capacity of these policies, with impacts on the analytical and operational capacities of this new institution, and on its human, financial and informational resources. From this inaugural moment, human resources at MDS have increased, even though this was not a steady process, particularly through the hiring of new civil servants, as depicted in Chart 3.

\section{Chart 3 - Quantitative of active federal civil servants in MDS}

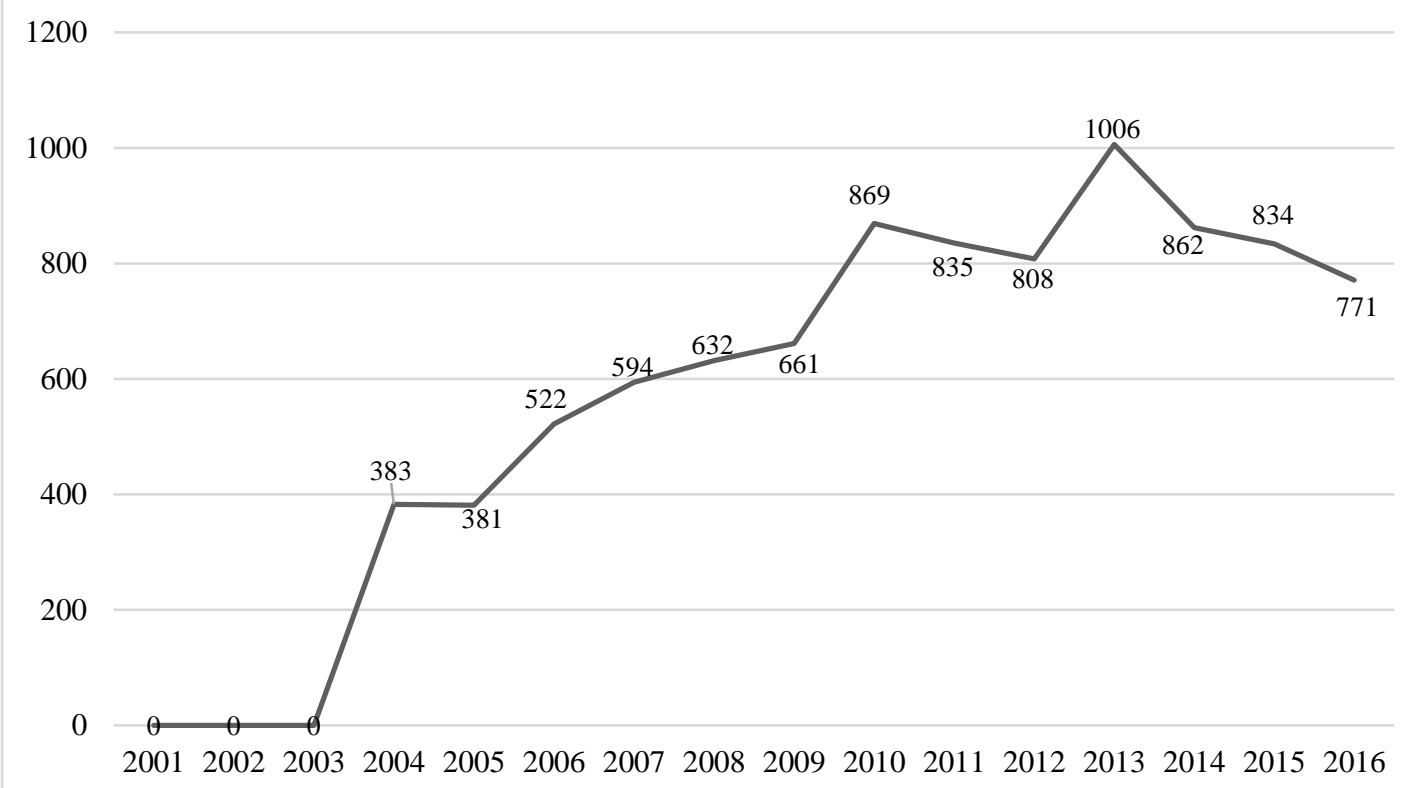

Source: Elaborated by the authors with data obtained in the Statistical Bulletin of Personnel and Organizational Information/ Ministry of Planning. Data range from 2003 to December 2016.

From 2003 to 2010, according to the Statistical Bulletin of Personnel and Organizational Information, from the Ministry of Planning, several civil service examinations were held to provide MDS with its general staff. In 2006, it held a civil service examination for 295 higher education and high school posts and a simplified selection process for 60 higher education temporary jobs. In 2008 there was another selection process for 110 higher education temporary jobs and in 2009, a civil service examination for 70 new high school posts. A review of MDS's structure in 2010 created 164 new posts for senior management and advisory positions. The civil service examination for the career of Social Policy Technical Analyst, in 2013, meant new posts to social ministries: 61 in 2014, and 142 in 2015.

However, similarly to what happened to MCIDADES, MDS's human resources had a discontinuous growth, reflecting changes in the political-economic context and in 
the dynamics between the political forces. Human resources at MDS declined at the beginning of Dilma's government, as well as from 2014 onwards, perhaps due to the economic retraction process that had already began. Despite the changes in the number of employees, the financial resources invested in this Ministry had a more stable trajectory of growth, as Chart 4 shows. There is also a downward trend in the percentage ratio between the resources earmarked for this ministry and the General Budget of the Union (OGU), beginning in 2014.

\section{Chart 4 - Budget allocation at MDS (Total Budget, including resources from Treasury and other sources) (in Reais)}

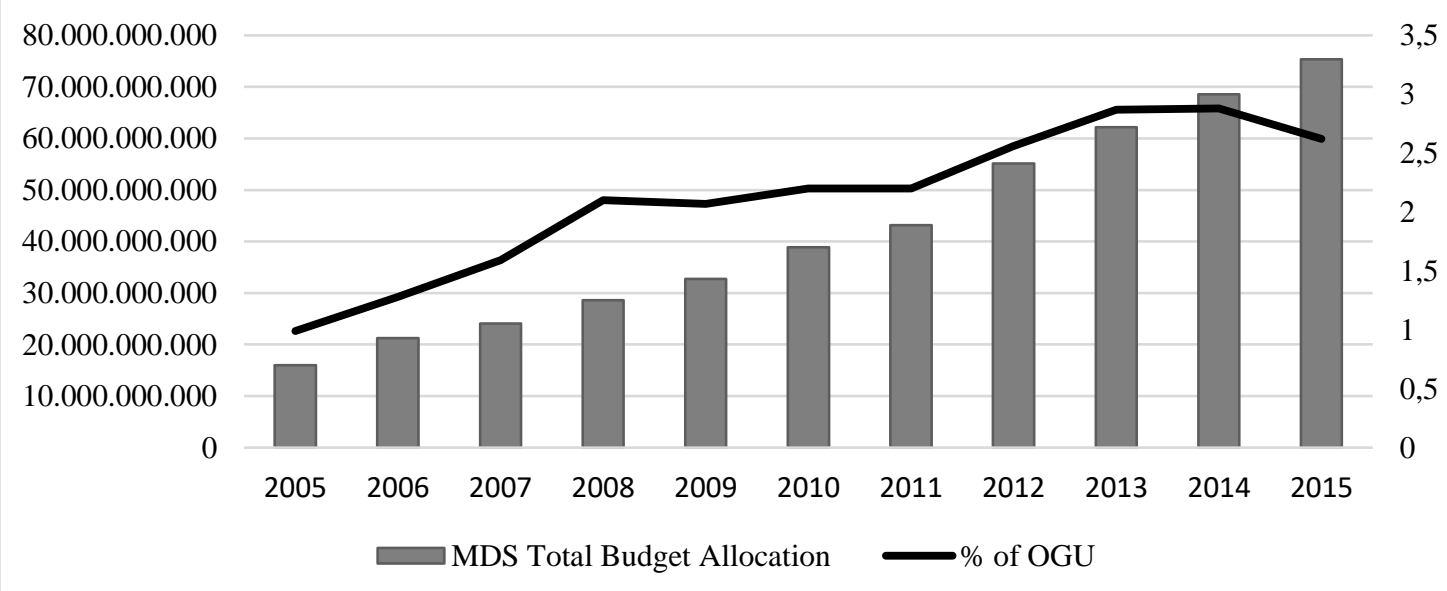

Source: Brazilian Budgetary Law 2006-2015.

Informational resources for PBF's management have also improved greatly during PT's government. Two examples stand out: Cadastro Único (CadÚnico) and Decentralized Management Index (IGD). CadÚnico is an instrument for collecting data and information to identify low-income families, defined as households earning up to half of the minimum wage per capita (about U\$ 128 per month). It was created in July 2001, during FHC's government, but it was only after 2003 that this family register increased exponentially, as Chart 5 depicts.

The effort to improve and systematize the registers from 2003 onwards is approached by several authors (SILVA et al., 2004; BICHIR, 2016). Roles of each level of government have become clearer and the responsibility for the CadÚnico was shared between MDS, states, municipalities and CAIXA. Increasingly, these actors used CadÚnico to identify potential beneficiaries of innumerous social programs, improving their ability to address poverty, and to optimize program management and its efficiency.

Chart 5 - Number of families registered at CadÚnico (in millions) 


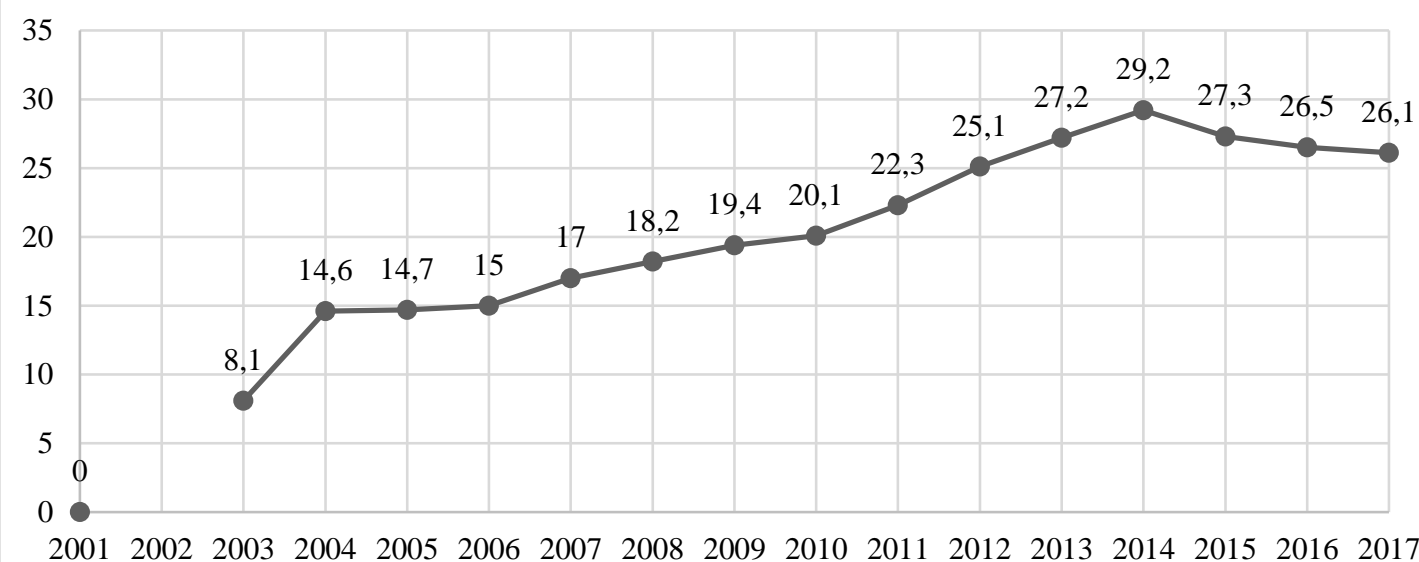

Sources: Data from 2003 to 2010: BRASIL, 2010b: 59. Data from 2011 to October 2017: https://aplicacoes.mds.gov.br/sagi/RIv3/geral/relatorio.php\#Visão Geral Brasil. Last acessed in November 2017.

In addition, MDS periodically measured the management quality of PBF and CadÚnico implementation, with a focus on subnational governments, using IGD, an index that ranges from zero to 1 . The closer to 1 , the better the management evaluation score. Based on this indicator, MDS calculated an extra amount of financial resources to be passed on to the subnational entities. These resources should be applied to improve the quality of local management of PBF and CadÚnico, including the acquisition of furniture and computer equipment, training, campaigns to mobilize and disseminate information, among others. Lastly, the relevance of SAGI - Secretariat for Evaluation and Information Management - in the process of building indicators and evaluations on MDS policies, is noteworthy. This served as a basis for improving programs and for providing evidence of their impact on the lives of the targeted population, contributing to increase support and legitimacy among society and other government agencies.

With almost 14 million families served in 2016 by PBF, recent research shows its contribution to the reduction of extreme poverty. Soares, Ribas and Osório (2010) point out that the program contributed $21 \%$ to the drop in the Gini index and $12 \%$ to poverty and $19 \%$ to extreme poverty. Kertenetzky (2009) reinforces the importance of the program for the reduction of poverty and inequality, considering the low percentage of the budget spent on it in relation to its cost. According to this author, between 2003 and 2014 there was the greatest historical reduction in absolute poverty in Brazil since 1976, a fall of $18 \%$. In 2017 , more than 3.4 million people stopped living in extreme poverty because of PBF, and 3.2 million left the poverty line (SouZA et al., 2019). 
In short, MDS also showcases how changes in the correlation of political forces and in their respective political-ideological orientations altered the capacity of the policies to fight poverty and hunger. The creation and consolidation of this ministry initiated a process of accumulation of resources and development of individual, organizational, and systemic capacities. This path, however, was altered by the new context and the changes in the correlation of forces between political actors in 2016, which led to the impeachment of President Dilma Rousseff and the rise of the following governments of Michel Temer and Jair Bolsonaro, which began to de-prioritize PBF and other social policies. As a consequence, there was an initial freezing and reduction in the financial and human resources made available to this ministry ${ }^{11}$, similarly to what happened to MCIDADES, which posteriorly led to their entire dismantlement and integration in other umbrella ministries in 2019.

\section{Final remarks}

The current debate on state capacity, despite practical relevance for policy-making and analytical advances in the last decades, is still permeated by several theoretical and methodological problems. This work has contributed to the literature on state capacity in three interrelated ways, which reinforce the analytical utility of this revised concept.

Firstly, we worked on the concept of state capacity, highlighting its specificities in regard to the generic notion of power. The former unravels the functioning of the state in action, offering the possibility of looking at how the result of the game of power among different political forces is reflected within the state, that is, how the state apparatus and the public policies are organized to carry out priority actions of the political group in power.

Secondly, departing from the recognition that state capacity is not a fixed attribute of the State, the article showed the relevance of bringing both contextual and political elements into the debate of capacity. We have depicted how changes in historicalconjunctural context and in the political-ideological orientations of dominant groups in government have engendered changes in the mobilization of resources. Furthermore, this

\footnotetext{
${ }^{11}$ According to data from the proposed Annual Budget Law (PLOA) of 2018, PBF's budget allocation has been reduced from 29 billion to 26 billion reais. As regards housing policies, the 2018 PLOA corroborates the trend of decline in investment: while in 2017 the estimated budget was 13.1 billion reais, in 2018, this value reached only 2,3 billion reais.
} 
concept of policy capacity, which specifies the generic notion of state capacity, permits to understand how programs prioritized in the governmental agenda can be built or reinforced inside the state apparatus. The indicators of this process are the activation or creation of resources - financial, human, and financial. Prioritization in the governmental agenda can be viewed as a necessary condition for the activation or mobilization of the stock of resources, even though it might be limited by external conditions and, therefore, not be a sufficient condition for policy capacity building.

Thirdly, by trying to surpass the criticisms related to the theoretical and methodological problems contained in the studies on state capacity, this research has helped to establish clearer boundaries between this notion and other concepts, such as resources and results. It was possible to depict the differentiation between capacity and resources. While the latter are a necessary condition for policy implementation, they do not guarantee per se policy capacity: a government becomes more capable of elaborating and implementing a policy if this area is a priority in the governmental agenda and it decides to create or activate existing stock of resources for this end. On the other hand, this study also clarified the connections between capacity and results: these can partly explain by government's capacity to implement a policy, but they are also determined by external elements, such as economic context. The fiscal policy, for example, may be an area where government has an excellent capacity in terms of mobilization of resources, but unable to deliver the desired results in terms of fiscal revenue due to an economic crisis or recession.

In addition, the analyses of the cases allow confirmation of our argument that historical contexts may have different effects on policies. As such, the fiscal function of the State related to public debt management currently has such importance in the globalized economy that this area of policy is viewed as a basic condition of government and, therefore, characterized by a continuous capacity-building process, remaining a relevant area with increasing allocation of resources in all the analyzed governments, in spite of different political-ideological orientations. The social policies, on the other hand, have assumed a more contingent and dependent character in relation to the dominant political forces in each government, and the resources mobilized to realize their potential of capacity suffered important oscillations. The recent dismantling in social policy areas coupled with the maintenance and expansion of the fiscal function of the State in the governments of Michel Temer and Jair Bolsonaro are clear evidence of these differences. 
Furthermore, the cases of MDS and MCIDADES suggest that different social policies present diverse degrees of resilience to keep unchanged their policy capacity when faced with major changes in the economic and political context and in the correlation of forces between political actors. From 2016 to 2018, MDS has had moderate budget cuts and has continued to implement, with minor changes, the Bolsa Familia Program, a low-cost initiative with considerable support in society. Even though it has received criticism, the program has been able to consolidate itself, both nationally and internationally, as a best practice to fight poverty and a relevant electoral issue, guaranteeing a greater likelihood of its continuity in the governmental agenda. On the other hand, Ministry of Cities had a considerable reduction in its budget allocation and programmatic execution. This was probably due to its higher cost, in the context of extreme cuts in public spending, but also due to growing concerns and criticisms about its legitimacy and effectiveness, as well as the various challenges related to the implementation of housing policy.

Finally, if this work on state capacity could bring some theoretical and empirical contributions, it is also necessary to highlight its limits. First, as mentioned previously, the findings of this research are contextually bounded, and it may be challenged by future developments. Secondly, the article does not incorporate policies that were not a priority in governmental agenda which could be used methodologically as contrafactual or intermediary cases. We expect future research to overcome these limits. The advancement of knowledge on this subject depends on the development of new studies about other policy areas - with or without prominence in the governmental agenda, and even in comparative perspective with other countries and other political, institutional and ideological contexts.

\section{References}

ABRUCIO, F. (2005). A coordenação federativa no Brasil: a experiência do período FHC e os desafios do governo Lula. Revista de Sociologia e Política, n. 24, p. 41-67.

Abrucio, F.; LOUREIRO, M. (2004). Política e reformas fiscais no Brasil recente. Revista de Economia Política, São Paulo, v. 24, n. 1, p. 50-72.

Além, A. C. \& Giambiagi, F. (2000). Finanças públicas: teoria e prática no Brasil. Rio de Janeiro: Campus. 
BELTRÃO, R. E. V. \& NOGUEIRA, F. DO A. The documentary research in recent studies in public administration and social management in brazil. IN: Conference Proceedings of the XXXV ANPAD Meeting. Rio de Janeiro, September 4 to 7, 2011.

Belluzzo, L.G \& AlmeidA, J. S. (2002). Depois da queda: A economia brasileira da crise da dívida aos impasses do Real. Rio de Janeiro: Civilização Brasileira.

BICHIR, R. (2016). Novas agendas, novos desafios: reflexões sobre as relações entre transferência de renda e assistência social no Brasil. Novos Estudos CEBRAP (Impresso), v. 104, p. 111-136.

(2016). A Emergência e a consolidação de programas de transferência de renda no Brasil, na Argentina e na África do Sul. In: GoMIDE, A. \& BOSCHI, R. (ed.s). Capacidades estatais em países emergentes: o Brasil em perspectiva comparada. Ed. Rio de Janeiro: Ipea.

BRASIL. (2010a). Urbanização de favelas: A experiência do PAC. Ministério das Cidades, Secretaria Nacional de Habitação. Brasília.

(2010b). Desenvolvimento Social e Combate à Fome no Brasil: Balanços e Desafios. Brasília, DF: MDS; Secretaria de Avaliação e Gestão da Informação, 2010 b.

CArdoso, A. L.; Aragão, T.; \& Araujo, F. (2011). Habitação de interesse social: Política ou mercado? Reflexos sobre a construção do espaço metropolitano. ENCONTRO NACIONAL DA ASSOCIAÇÃO DE PÓS-GRADUAÇÃO E PESQUISA EM PLANEJAMENTO URBANO E REGIONAL, XIV, 2011, Rio de Janeiro. Anais. Rio de Janeiro: ANPUR.

CARdoso, A. L. \& RiBeIRO, L. C. Q. (2002). A municipalização das políticas habitacionais: Uma avaliação recente (1993-1996). Relatório final, Parte I. Rio de Janeiro: IPPUR/FASE.

CARdoso, A. L. \& DenAldi, R. (orgs.). (2018). Urbanização de favelas no Brasil: Um balanço preliminar do PAC. 1. ed. Rio de Janeiro: Letra Capital.

CARdoso, Fernando Henrique. (1994). Plano Fernando Henrique Cardoso. Exposição de motivos n³95, de 7 de dezembro de 1993. Revista de Economia Política, vol. 14, nº (54), abril-junho.

CARDOSO JR. \& JACCOUd, L. (2005). Políticas sociais no Brasil: Organização, abrangência e tensões da ação estatal. In: JACCOUD, L. (Org.), Brasília: Ipea.

CingOlani, L. (2013). The state of State capacity: A review of concepts, evidence and measures. Working Paper, n. 53. Maastricht: UNU-MERIT.

DIAS, E.C. (2012). Trajetórias e agendas na rearticulação da política habitacional brasileira: o governo federal e os empresários da construção (1994-2010). II Seminário Discente da PósGraduação em Ciência Política da Universidade de São Paulo.

ENRIQUeZ, E. \& CENTENO, M. A. (2012). State capacity: Utilization, durability, and the role of wealth vs. history. International and Multidisciplinary Journal of Social Sciences, v. 1, n. 2, p. 130-162.

EVANS, P. (1995). Embedded autonomy: States and industrial transformation. Princeton, NJ: Princeton University Press. da UFRJ.

(2004). Autonomia e parceria: Estados e transformação industrial. Rio de Janeiro: Ed. 
Gomide, A. A.; Pereira, A. K.; \& Machado, R. (2017). Apresentação: O conceito de capacidade estatal e a pesquisa científica. Soc. e Cult., Goiânia, v. 20, n. 1, p. 3-12.

(2018). The concept of state capacity and its operationalization in Empirical Research. International Workshop On Public Policy, International Public Policy Association (IPPA), Pittsburgh, PA.

GOMIDE, A. A. \& PIRES, R. R. C. (2014). Capacidades estatais e democracia: arranjos institucionais de políticas públicas. Brasília: Ipea.

HANSON, J. \& Sigman, R. (2011). Measuring state capacity: Assessing and testing the options. In: American Political Science Association.

KerstenetZKy, C. L. (2009). Redistribuição e desenvolvimento? A Economia Política do Programa Bolsa Família. Dados, Revista de Ciências Sociais, Rio de Janeiro, vol. 52, nº 1 .

KLINTOWITZ, D. (2015). Entre a reforma urbana e a reforma imobiliária: A coordenação de interesses na política habitacional brasileira nos anos 2000. Tese (Doutorado em Administração Pública e Governo) - Escola de Administração de Empresas de São Paulo da Faculdade Getúlio Vargas, São Paulo.

KOCHER, M. (2010). State Capacity as a conceptual variable. Yale Journal of International Affairs, 5(2).

LiMA-SILVA, F. \& LOUREIRO, M. R. (2018). Ceder e controlar o poder: Estratégias presidenciais para coordenação governamental no Brasil. Revista do Serviço Público, 69 (3), 529-558, jul./set..

LiNDVAll, J.; TEORELL, J. (2016). State capacity as power: A conceptual framework. (STANCE Working Paper Series, n. 1). Lund: Department of Political Science, Lund University.

LOPREATO, F. L. C. (2006). O papel da política fiscal: Um exame da visão convencional. Texto para Discussão. IE/UNICAMP n. 119, fev. .

LOUREIRO, M. R.; MACARIO, V.; \& GUERRA, P. (2013). Democracia, arenas decisórias e políticas públicas: O Programa Minha Casa Minha Vida. Texto para discussão 1886, Instituto de Pesquisa Econômica Aplicada (IPEA), Rio de Janeiro, outubro.

Loureiro, M. R.; Santos, F. P.; \& Gomide, A. A. (2011). Democracia, arenas decisórias e política econômica no governo Lula. Revista Brasileira de Ciências Sociais, v. 26, n. 76, p. 6576.

MAHONEY, J. (2005). Qualitative methodology and comparative politics. Annual Meetings of the American Political Science Association. Washington D.C, September 1-2, .

MARICATO, E. (2012). O impasse da política urbana no Brasil. $2^{\circ}$ ed. - Petrópolis: Editora Vozes.

MARQUeS, E. (2017). Housing policy in Brazil. Paper presented on Workshop "Housing, Livelihoods and Environmental Challenges in Urban India and Brazil", 6-8 February. Organized by Center for Development and Environment Policy, IIM Calcutta, p.1-19.

MARQUES, E. C. L. (Coord.). (2007). Assentamentos precários no Brasil urbano. Brasília/São Paulo: Ministério das Cidades/CEM.

MIRANDA, José Carlos. (1997). Dinâmica financeira e política macroeconômica. In: TAVARES, Maria da Conceição \& FIORI, José Luis (orgs). Poder e Dinheiro. Petrópolis, RJ: Vozes. 
Oliveira. G. \& TUROLla, F. (2003). Política econômica do segundo governo FHC: Mudanças em condições adversas. Tempo social, vol 15, no 2 nov.

Ramos, A. P. (2001). A política fiscal do Plano Real e o ajuste fiscal para 1999-2001. Revista de Economia Política, out/dez, vol. 21, no 4(84).

RochA, K. de L. (2009). Estrutura institucional e eventos recentes na História da Administração da Dívida Pública Federal. In: Dívida Pública. A experiência brasileira. Anderson Caputo Silva, Lena Oliveira de Carvalho, Otávio Ladeira de Medeiros (organizadores). Brasília: Secretaria do Tesouro Nacional: Banco Mundial.

RolniK, R.; KLINTOWITZ, D.; IACOVINI, R. F. G. (2014). Habitação em municípios paulistas: Construir políticas ou "rodar" programas? Revista Brasileira de Estudos Urbanos e Regionais, v. 16, n. 2, p. 149-165.

Rowley, J. (2002). Using case studies in research. Management Research News, Volume 25, Number 1.

SAGUIN, K; TAN, S. Y.; \& GOYAL, N. (2018). Mapping scientific research on policy capacity: A bibliometric analysis and qualitative framework synthesis. International Workshop on Public Policy, International Public Policy Association (IPPA), Pittsburgh, PA.

Schneider, B. R. \& Doner, R. F. (2000). The New Institutional Economics, Business Associations, and Development. Brazilian Journal of Political Economy 20 (3).

SeCretaria Do Tesouro Nacional (STN). (2006). Secretaria do Tesouro Nacional, 20 anos: um marco institucional na história econômica do Brasil. Brasília: Secretaria do Tesouro Nacional.

SIKKINK, K. (1991). Ideas and Institutions: Developmentalism in Brazil and Argentina. Cornell University Press. Ithaca and London.

SiNGER, André. (2012). Os sentidos do lulismo: Reforma gradual e pacto conservador. São Paulo, Companhia das Letras.

Silva, M. O.; YAZBEK, M. C.; Di GiovanNI, G. (2004). A política brasileira no século XXI: A prevalência dos programas de transferência de renda. São Paulo: Cortez.

SiLVA, L. (2015). A burocracia de médio escalão da Secretaria da Receita Federal do Brasil: insulamento seletivo e construção de capacidades burocráticas. In: Burocracia de médio escalão: perfil, trajetória e atuação / organizadores Pedro Luiz C. Cavalcante e Gabriela S. Lotta. Brasília: ENAP.

SKOCPOL, T. (1979). States and social revolutions: A comparative analysis of France, Russia and China. New York and Cambridge: Cambridge University Press.

SKOCPOL, T. (1985). Bringing the state back in: Strategies of Analysis in Current Research. In: EVANS, P. B.; RUESCHEMEYER, D.; \& SKOCPOL, T. Bringing the state back in. Cambridge: Cambridge University Press.

SOARES, F. V.; RIBAS, R. P.; OSÓRIO, R. E. (2010). Evaluating the impact of Brazil's Bolsa Família: Cash Transfer Programs in comparative perspective. Latin American Research Review. Latin America Studies Association: v. 45, n. 2, p. 173-190. 
SoAres, S.; SouzA, P. H. G. F.; Osório, R. G.; \& Silveira, F. G. (2010). Os impactos do benefício do programa bolsa família sobre a desigualdade e a pobreza. In: CASTRO, J. A.; Modesto, L. Bolsa Família 2003-2010: avanços e desafios. Brasília, DF: IPEA, v. 1, p. 25-26.

SoAReS, S. \& SÁtYro, N. (2009). O Programa Bolsa Família: Desenho institucional, impactos e possibilidades futuras. IPEA: Texto para Discussão 1424. Brasília, outubro.

SOUZA, P. H. G.; OSORIO, R. G.; PAIVA, L. H.; \& SOARES, S. (2019). Os efeitos do programa bolsa família sobre a pobreza e a desigualdade: Um balanço dos primeiros quinze anos. IPEA: Texto para Discussão 2499. Rio de Janeiro, agosto.

YIN, R. K. (1994). Case study research: design and methods. $2^{\text {nd }}$ edition. Thousand Oaks, CA: Sage.

Wu, X; RAMesh, M.; \& Howlett, M. (2015). Policy capacity: A conceptual framework for understanding policy competences and capabilities. Policy and Society, v. 34, p. 165-171.

\section{Fernanda Lima-Silva}

https://orcid.org/0000-0003-4838-7075

$\mathrm{PhD}$. in Public Administration and Government from the Fundação Getulio Vargas - Escola de Administração de Empresas de São Paulo (FGV EAESP). Postdoctoral researcher at Centro de Administração Pública e Governo (Ceapg) in FGV EAESP.

E-mail: fernanda.silva@fgv.br

\section{Maria Rita Loureiro}

https://orcid.org/0000-0003-3129-4956

Full professor of Public Administration and government of FGV/SP and retired professor from FAculty of Economics and Management of University of São Paulo (FEA/USP). Master and Doctorate in Sociology from the University of São Paulo, with a post-doctorate in Sociology from the École des Hautes Études en Sciences Sociales de Paris and in Political Science from the New York Univers.

E-mail: marita.loureiro@gmail.com

\section{Adriana Aranha}

(iD) https://orcid.org/0000-0001-6912-9724

Master in Public Administration from Fundação João Pinheiro and a Doctorate in Public Administration and Government from Fundação Getulio Vargas - Escola de Administração de Empresas de São Paulo (FGV EAESP), with a doctoral internship at the Center for Social Studies at the University of Coimbra. E-mail: adriana.veiga.aranha@gmail.com

\section{Felipe Calabrez}

iD https://orcid.org/0000-0002-3890-6778

Master in Political Science from the Federal University of Parana (UFPR) and a Doctorate in Public Administration and Government at Fundação Getulio Vargas Escola de Administração de Empresas de São Paulo (FGV EAESP).

E-mail: f.calabrez@hotmail.com 